\title{
High Hes1 expression and resultant Ascl1 suppression regulate quiescent vs. active neural stem cells in the adult mouse brain
}

\author{
Risa Sueda, ${ }^{1,2,7}$ Itaru Imayoshi, ${ }^{1,2,3,4,5,7}$ Yukiko Harima, ${ }^{1}$ and Ryoichiro Kageyama ${ }^{1,2,3,5,6}$ \\ ${ }^{1}$ Institute for Frontier Life and Medical Sciences, Kyoto University, Kyoto 606-8507, Japan; ${ }^{2}$ Graduate School of Biostudies, Kyoto \\ University, Kyoto 606-8501, Japan; ${ }^{3}$ Research Center for Dynamic Living Systems, Graduate School of Biostudies, Kyoto \\ University, Kyoto 606-8501, Japan; ${ }^{4}$ Precursory Research for Embryonic Science and Technology, Japan Science and Technology \\ Agency, Saitama 332-0012, Japan; ${ }^{5}$ Institute for Integrated Cell-Material Sciences (iCeMS), Kyoto University, Kyoto 606-8501, \\ Japan; ${ }^{6}$ Graduate School of Medicine, Kyoto University, Kyoto 606-8501, Japan
}

Somatic stem/progenitor cells are active in embryonic tissues but quiescent in many adult tissues. The detailed mechanisms that regulate active versus quiescent stem cell states are largely unknown. In active neural stem cells, Hes1 expression oscillates and drives cyclic expression of the proneural gene Ascl1, which activates cell proliferation. Here, we found that in quiescent neural stem cells in the adult mouse brain, Hes1 levels are oscillatory, although the peaks and troughs are higher than those in active neural stem cells, causing Ascl1 expression to be continuously suppressed. Inactivation of Hes1 and its related genes up-regulates Ascl1 expression and increases neurogenesis. This causes rapid depletion of neural stem cells and premature termination of neurogenesis. Conversely, sustained Hes1 expression represses Ascl1, inhibits neurogenesis, and maintains quiescent neural stem cells. In contrast, induction of Ascl1 oscillations activates neural stem cells and increases neurogenesis in the adult mouse brain. Thus, Ascl1 oscillations, which normally depend on Hes1 oscillations, regulate the active state, while high Hes1 expression and resultant Ascl1 suppression promote quiescence in neural stem cells.

[Keywords: active neural stem cell; Ascl1; Hes1; notch signaling; oscillatory expression; quiescent neural stem cell]

Supplemental material is available for this article.

Received December 4, 2018; revised version accepted February 26, 2019.

Somatic stem/progenitor cells actively divide and give rise to many mature cells in embryonic tissues, whereas they are usually dormant/quiescent in many adult tissues. For example, muscle stem/progenitor cells derived from the dermomyotome of the somite actively proliferate and generate skeletal muscles in embryos, whereas satellite cells in the adult skeletal muscle, known as muscle stem cells, are quiescent (Shi and Garry 2006). When muscles are injured, satellite cells are activated and contribute to muscle regeneration. Similarly, in the developing nervous system, neural stem/progenitor cells (neuroepithelial cells and radial glial cells) actively divide and sequentially produce many neurons and glial cells (Alvarez-Buylla et al. 2001; Götz and Huttner 2005). Neural stem cells are also present in two regions of the adult mouse brain: the subgranular zone (SGZ) of the hippocampal dentate gyrus and the subventricular zone (SVZ) of the lateral ventricles (Doetsch 2003; Kriegstein and Alvarez-Buylla 2009). These adult neural stem cells are mostly quiescent/dormant and only occasionally divide to produce some new

\footnotetext{
${ }^{7}$ These authors contributed equally to this work.

Corresponding author: rkageyam@infront.kyoto-u.ac.jp, imayoshi.itaru. 2n@kyoto-u.ac.jp

Article published online ahead of print. Article and publication date are online at http://www.genesdev.org/cgi/doi/10.1101/gad.323196.118. Freely available online through the Genes \& Development Open Access option.
}

neurons, which integrate into the pre-existing neural circuits (Seri et al. 2001; Lagace et al. 2007; Imayoshi et al. 2008a; Bonaguidi et al. 2011; Encinas et al. 2011; Pilz et al. 2018). The molecular nature of such differences between the embryonic active state and adult quiescent state of stem cells remains to be analyzed.

The process of activating quiescent neural stem cells in the adult brain has been intensively analyzed. A small fraction of neural stem cells (type 1 cells in the SGZ and type B cells in the SVZ) is activated to produce transit-amplifying cells (type 2 cells in the SGZ and type C cells in the SVZ), which proliferate and soon generate neuroblasts (type 3 cells in the SGZ and type A cells in the SVZ). These neuroblasts then migrate into the granular layer of the dentate gyrus (from the SGZ) and the olfactory bulb (from the SVZ). The proneural gene Ascl1 plays a critical role in the activation of quiescent neural stem cells and subsequent formation of neuroblasts in the mouse brain. Ascll is expressed at low levels by some activated neural stem cells (type 1 and type B cells) and at high levels by transit-amplifying cells (type 2 and type C cells) (Pastrana et al. 2009; Kim et al. 2011; Andersen et al. 2014).

(C) 2019 Sueda et al. This article, published in Genes \& Development, is available under a Creative Commons License (Attribution-NonCommercial 4.0 International), as described at http://creativecommons.org/licenses/by-nc/4.0/. 
Furthermore, live-imaging analysis showed that Ascl1expressing neural stem cells exclusively generate neurons in the adult mouse hippocampus (Pilz et al. 2018). In contrast, in the absence of Ascl1, all neural stem cells remain quiescent, and type 2 cells are never formed in the hippocampus, indicating that Ascl1 is absolutely required for activation of quiescent neural stem cells (Andersen et al. 2014). However, it was shown that overexpression of Ascl1 in adult hippocampal neural stem cells leads to exclusive generation of oligodendrocytes at the expense of neurons (Jessberger et al. 2008). Thus, the detailed mechanisms of how Ascl1 expression is controlled and how Ascll activates quiescent neural stem cells to induce neurogenesis are unknown.

Accumulating evidence indicates that Notch signaling plays an essential role in maintaining quiescent neural stem cells in the adult brain. Inactivation of the Notch pathway up-regulates Ascll expression, activates neural stem cells, and transiently enhances neurogenesis, but neural stem cells are soon depleted, ending neurogenesis prematurely (Ables et al. 2010; Ehm et al. 2010; Imayoshi et al. 2010; Andersen et al. 2014). Activation of Notch signaling induces the transcriptional repressor Hes1, and Hes1 suppresses Ascll expression, which may contribute to the quiescence of adult neural stem cells. However, Notch signaling is also required for maintaining active neural stem cells in the embryonic brain (Mason et al. 2005; Mizutani et al. 2007; Imayoshi et al. 2010). How Notch signaling regulates both the active and quiescent states of neural stem cells is unknown. One possible mechanism may be involved in the expression dynamics of Hes1. In multipotent embryonic neural stem cells, Hes1 expression autonomously oscillates, and these oscillations periodically repress Ascl1 expression, thereby driving Ascll oscillations (Shimojo et al. 2008; Imayoshi et al. 2013). Optogenetic gene expression analysis showed that sustained Ascll expression induces cell cycle exit and neuronal differentiation, whereas oscillatory Ascll expression activates the proliferation of neural stem cells (Imayoshi et al. 2013), suggesting that Hes1 oscillation-induced Ascll oscillation may be involved in activating neural stem cells. These observations raised the possibility that the expression patterns of the Notch effector Hes 1 might be different in active and quiescent neural stem cells.

To understand the mechanism controlling active versus quiescent states of neural stem cells, we examined the expression and functions of Hesl and Ascll in the adult brain and found that Hes1-induced sustained suppression of Ascll expression contributes to the quiescent state of adult neural stem cells. We also found that inducing Ascll oscillation can activate neural stem cells and generate new neurons in the adult brain.

\section{Results}

Hes1 and Ascl1 expression patterns in the adult mouse brain

We first investigated Hes1 expression in the brains of adult Nestin-mCherry mice, in which neural stem cells were labeled with mCherry. Hes1 was specifically expressed at variable levels by Nestin-mCherry ${ }^{+}$GFAP $^{+}$ neural stem cells in both the SVZ and SGZ (Fig. 1A,F). To quantify the Hesl expression levels, we next used Venus-Hes1 fusion knock-in mice, in which Venus (GFP variant) cDNA was knocked-in in-frame into the $5^{\prime}$ region of the Hes1 gene so that the Venus-Hes1 fusion protein was expressed (Imayoshi et al. 2013). In these mice, Venus expression correlated very well with the endogenous Hes1 expression (Imayoshi et al. 2013), and we used a GFP antibody to detect Hes1 expression. Levels of Hes1 were higher and more variable in quiescent neural stem cells $\left(\mathrm{Ki}^{-} 7^{-}\right)$ than in active neural stem cells $\left(\mathrm{Ki} \mathrm{7}^{+}\right)$(Fig. 1B-E,G-J). To examine the Hes1 expression dynamics, we next used the Hes1 reporter mice, in which firefly luciferase (Luc2) cDNA was inserted in-frame into the $5^{\prime}$ region of the Hes1 gene in a bacterial artificial chromosome (BAC) clone so that the Luc2-Hes1 fusion protein was expressed (Imayoshi et al. 2013). The expression of the reporter in these mice was very similar to endogenous expression (Imayoshi et al. 2013). Neural stem cell lines (NS cells) established from the ventral telencephalon of these mice were cultured, and their luciferase activity was monitored. These cells were actively dividing in the presence of epidermal growth factor (EGF) and basic fibroblast growth factor (bFGF) but became quiescent in the presence of bone morphogenetic protein (BMP) and bFGF, as observed in other neural stem cell cultures (Mira et al. 2010; Martynoga et al. 2013). Time-lapse imaging analysis indicated that Hes1 protein expression oscillated at lower levels in these NS cells when they were in an active state (Supplemental Fig. S1A). When these cells were switched to a quiescent condition, Hes1 expression was still oscillatory but highly up-regulated (Supplemental Fig. S1B,C). Importantly, under this condition, Hesl expression was not completely repressed even at trough phases but rather was as high as peak levels of Hes1 oscillations in active NS cells. When these cells were returned to an active condition, Hes 1 expression was down-regulated and oscillated at lower levels (Supplemental Fig. S1D). We next performed time-lapse imaging of adult brain slices of the Hes1 reporter mice crossed with Nestin-mCherry mice. In both the SGZ and SVZ regions, Hes1 expression oscillated at high levels in most of the $\mathrm{mCherry}^{+}$neural stem cells (Fig. 1K,L; Supplemental Fig. S2A,B). Together, these results indicated that Hesl expression is oscillatory but high in quiescent neural stem cells.

We next examined Ascll expression using the Ascl1 reporter mice, in which Luc2 cDNA was inserted in-frame into the $5^{\prime}$ region of the Ascll gene in a BAC clone so that the Luc2-Ascl1 fusion protein was expressed (Imayoshi et al. 2013). NS cells established from the ventral telencephalons of these mice were cultured. Immunostaining showed that Ascll expression exhibited a "salt and pepper" pattern in the active state (Supplemental Fig. S1E) but was negative in the quiescent state (Supplemental Fig. S1F). Time-lapse imaging of luciferase activity indicated that Ascl1 protein expression was mostly negative in these NS cells when they were in a quiescent state, whereas it was up-regulated and oscillated when these 

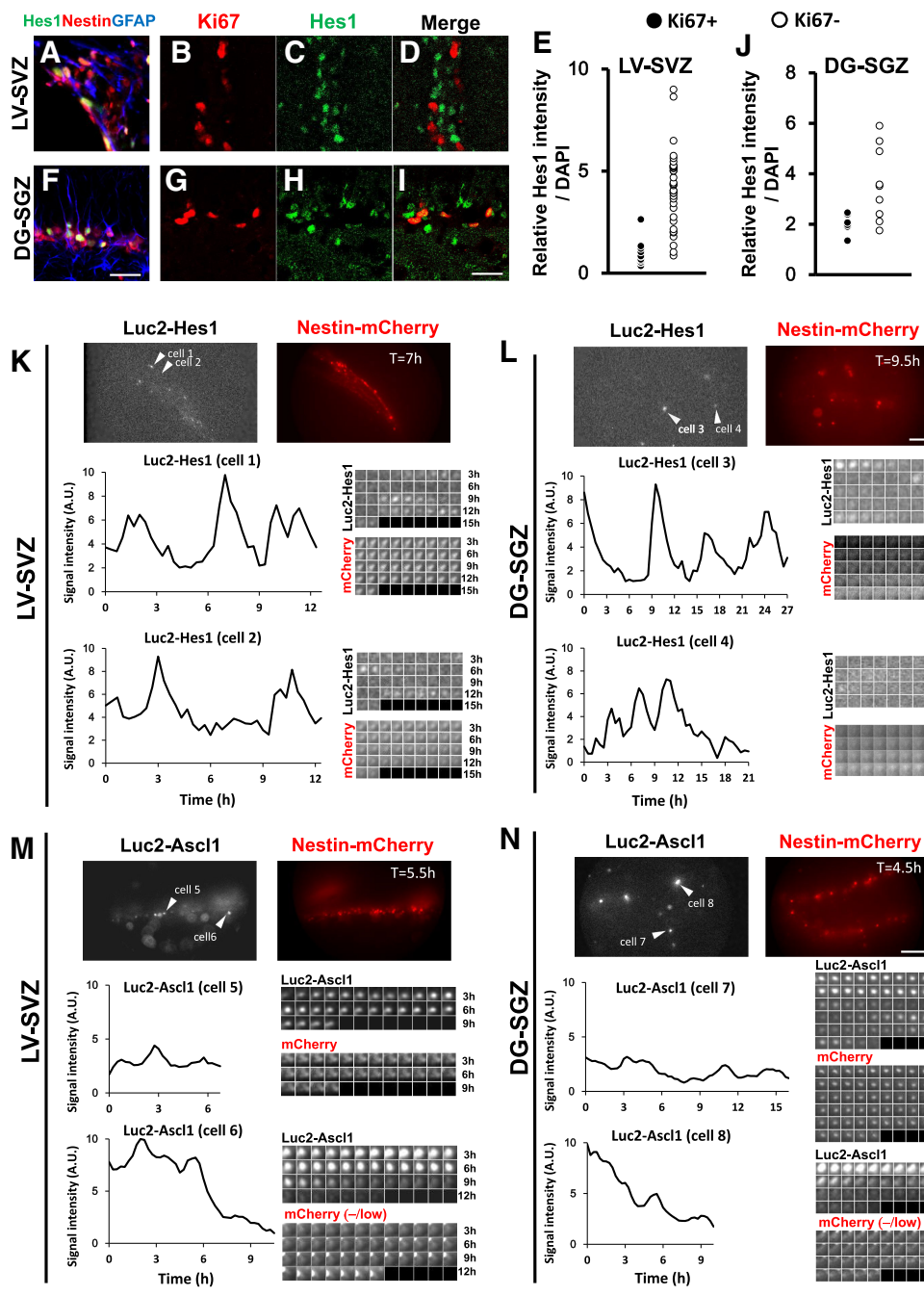

\section{更}

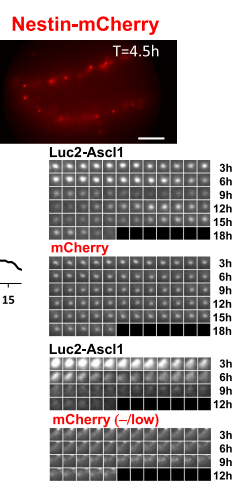

Figure 1. Variable levels of Hes1 and Ascl1 in neural stem cells in the adult mouse brain. $(A, F)$ Immunostaining of Hes 1 in the SVZ of the lateral ventricle (LV-SVZ; $A$ ) and the SGZ of the dentate gyrus (DG-SGZ; $F$ ) of Nestin-mCherry mice (2 mo of age). $(B-E, G-J)$ Hes1 levels in active $\left(\mathrm{Ki} 67^{+}\right)$and quiescent $\left(\mathrm{Ki}^{-} 7^{-}\right)$neural stem cells in the LV-SVZ $(B-E)$ and the DG-SGZ $(G-J)$ of the Venus-Hes1 fusion knock-in mice (2 mo of age) were examined. $(E, J)$ Hes1 levels in active $\left(\mathrm{Ki}_{6} 7^{+}\right)$and quiescent $\left(\mathrm{Ki}^{-} 7^{-}\right)$neural stem cells were quantified. $(K, L)$ Bioluminescence imaging and quantification of Luc2-Hes1 levels in Nestin-mCherry ${ }^{+}$ cells in slice cultures of the LV-SVZ $(K)$ and the DG-SGZ $(L) .(M, N)$ Bioluminescence imaging and quantification of Luc2-Ascll levels in slice cultures of the LV-SVZ $(M)$ and DG-SGZ $(N)$. Luc2-Ascll levels were quantified in both Nestin-mCherry ${ }^{+}$neural stem cells and Nestin$\mathrm{mCherry}^{- \text {low }}$ transit-amplifying cells. Note that Luc2-Ascl1 levels are higher in Nestin$\mathrm{mCherry}^{-/ \text {low }}$ transit-amplifying cells than in Nestin-mCherry ${ }^{+}$neural stem cells. Next to cell 6 , there is a Nestin-mCherry ${ }^{+}$neural stem cell, which is negative for Luc2-Ascl1 expression. Scale bars: $25 \mu \mathrm{m}(A-D, F-I) ; 100 \mu \mathrm{m}(K-N)$. cells were switched to an active condition (Supplemental Fig. S1G). We next performed time-lapse imaging of adult brain slices of the Ascll reporter mice crossed with Nestin-mCherry mice. In both the SGZ and SVZ regions, Ascll expression oscillated in subsets of $\mathrm{mCherry}^{+}$neural stem cells at lower levels (Fig. 1M [cell 5], N [cell 7]; Supplemental Fig. S2C [cells 7 and 8], D [cells 10 and 11]). The expression occurred at higher levels in mCherry-negative/ low transit-amplifying cells (Fig. 1M [cell 6], N [cell 8]; Supplemental Fig. S2C [cell 9], D [cell 12]). It was shown previously that Ascll is expressed by only a third of the active neural stem cell population as well as by transitamplifying cells (Andersen et al. 2014). Thus, it is likely that because Ascll expression is oscillatory, it occurs in the majority (if not all) of activated neural stem cells even though a snapshot shows that only one-third of them express Ascl1.

\section{Activation of adult neurogenesis by inactivation of Hes genes}

The above expression analyses suggested that Hes1 expression was high in quiescent neural stem cells. We next ex- amined whether Hes1 is required to maintain these cells in the adult brain. Hes1 was conditionally knocked out by crossing Hes1-floxed mice with Nes-CreER ${ }^{\mathrm{T} 2}$ mice, in which tamoxifen-inducible Cre recombinase was specifically expressed by neural stem cells (Imayoshi et al. 2006). Tamoxifen was administered to Nes-CreER ${ }^{\mathrm{T} 2}$; Hes1-floxed mice at 2 mo of age to induce Hes 1 ablation in neural stem cells, but we did not see any significant defects in the maintenance of quiescent neural stem cells (data not shown). This is probably because the Hes1 deficiency was compensated for by other Hes and Hes-related genes, such as Hes5 and Hey1, as reported previously (Hatakeyama et al. 2004; Imayoshi et al. 2008b).

We next generated Hes $1^{\text {floxed/floxed }} ; \mathrm{HeS3}^{-{ }^{--}} ; \mathrm{HeS}^{-/-}$; Hey $1^{-1-}$ mice and Nes-CreER ${ }^{\mathrm{T} 2}{ }_{\text {i Hes }} 1^{\text {floxed/floxed }}{ }_{;} \mathrm{Hes}{ }^{-/-}$; Hes $5^{-1-} ; \mathrm{Hey}^{-1-}$ mice. In the former mice, the maintenance of quiescent neural stem cells was not significantly affected, probably because Hes1 compensated for the Hes3, Hes5, and Hey1 deficiencies, and therefore these mice were used as controls (Fig. 2; Supplemental Fig. S3). To inactivate Hes1, tamoxifen was administered to Nes-CreER ${ }^{\mathrm{T} 2}{ }_{\text {;Hes }} 1^{\text {floxed/floxed }}{ }_{\text {Hes }}{ }^{-/-}{ }_{; H e s 5^{-/}} ; \mathrm{Hey} 1^{-/-}$ mice at 2 mo of age (referred to here as Hes1/3/5/Hey1 

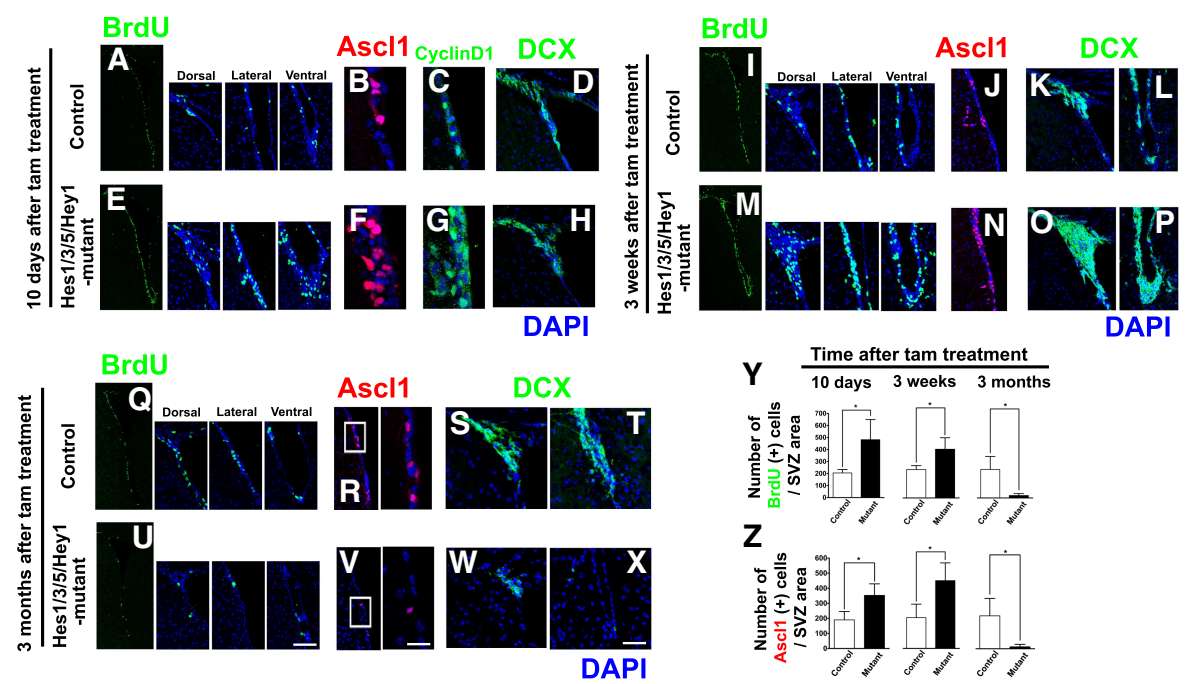

Time after tam treatment
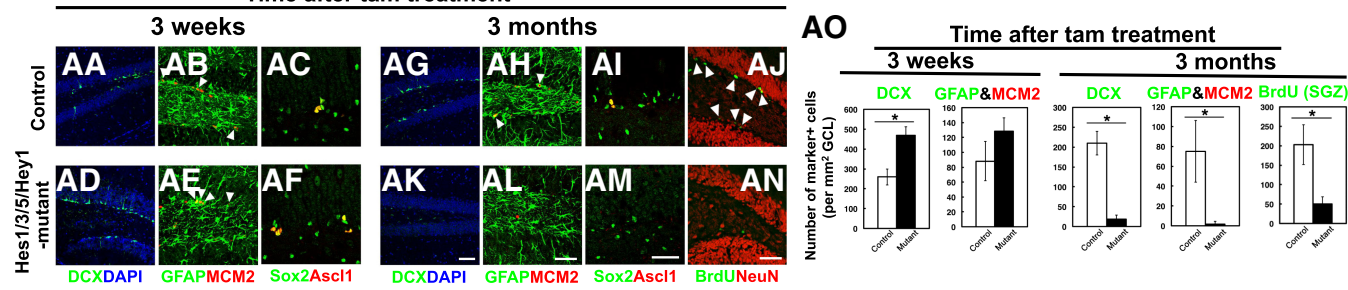

Figure 2. Up-regulation of Ascl1 and premature loss of neural stem cells in the adult brains of Hes1/3/5/Hey1 mutant mice. Coronal sections of the SVZ of the lateral ventricles $(A-Z)$ and the SGZ of the hippocampal dentate gyrus $(A A-A O)$ of $H e s 1^{\text {floxed/floxed }}$;Hes $3^{-/-}$; Hes5 ${ }^{-/} ;$Hey $1^{-/-}$mice (control) and Hes1/3/5/Hey1 mutant mice were examined by immunohistochemistry. BrdU was administered for $2 \mathrm{~h}$ before sacrifice. $(A-H)$ Control $(A-D)$ and Hes1/3/5/Hey1 mutant mice that were treated with tamoxifen $10 \mathrm{~d}$ before $(E-H)$. $(I-P)$ Control $(I-L)$ and Hes1/3/5/Hey1 mutant mice that were treated with tamoxifen 3 wk before $(M-P)$. $(Q-X)$ Control $(Q-T)$ and Hes1/3/5/Hey1 mutant mice that were treated with tamoxifen 3 mo before $(U-X)$. Boxed regions in $R$ and $V$ are enlarged at the right. $(Y, Z)$ Quantification of $\operatorname{BrdU}^{+}(Y)$ and $\operatorname{Ascll}^{+}(Z)$ cells in control and Hes1/3/5/Hey1 mutant mice that were treated with tamoxifen $10 \mathrm{~d}($ left $), 3 \mathrm{wk}$ (middle), and 3 mo (right) before BrdU administration. $(A A-A N)$ Control $(A A-A C, A G-A J)$ and Hes1/3/5/Hey1 mutant mice that were treated with tamoxifen $3 \mathrm{wk}(A D-A F)$ and $3 \mathrm{mo}(A K-A N)$ before. $(A J, A N) \mathrm{BrdU}$ was given for seven consecutive days before sacrifice. $(A O)$ Quantification of $\mathrm{DCX}^{+}, \mathrm{GFAP}^{+} \mathrm{MCM}^{+}$, and $\mathrm{BrdU}^{+}$cells in control and Hes1/3/5/Hey1 mutant mice that were treated with tamoxifen 3 wk (left) and 3 mo (right) before. $\left({ }^{*}\right) P<0.05$, Student's $t$-test. Scale bars, $50 \mu \mathrm{m}$.

mutant mice), and brains were examined $10 \mathrm{~d}$ later. In the Hes1/3/5/Hey1 mutant SVZ, the numbers of Ascl1-positive cells and BrdU-incorporating and CyclinD1 $1^{+}$dividing cells significantly increased compared with the brains of control mice (Fig. 2A-C,E-G, Y [left panel], Z [left panel]). At this stage, neuroblasts $\left(\mathrm{DCX}^{+}\right)$in the mutants were not much different than in the controls (Fig. 2D,H). Three weeks after tamoxifen treatment, the numbers of both Ascll-positive and BrdU-incorporating dividing cells and $\mathrm{DCX}^{+}$neuroblasts significantly increased compared with in the controls (Fig. 2I-P,Y [middle panel], $\mathrm{Z}$ [middle panel]). However, 3 mo after tamoxifen treatment, Ascll expression mostly disappeared, and the numbers of BrdU-incorporating dividing cells and $\mathrm{DCX}^{+}$ neuroblasts significantly decreased in Hes1/3/5/Hey1 mutants compared with in the controls (Fig. 2Q-X,Y [right panel], Z [right panel]). Similarly, in the mutant hippocampal dentate gyrus, the number of $\mathrm{DCX}^{+}$neuroblasts increased compared with in the controls $3 \mathrm{wk}$ after tamoxifen treatment (Fig. 2AA,AD,AO). Furthermore, the number of active neural stem cells $\left(\mathrm{GFAP}^{+}{ } \mathrm{MCM}^{+}{ }^{+} \mathrm{Ascl1}^{+}\right)$ tended to be higher in the mutant dentate gyrus than in the controls (Fig. 2AB, AC, AE, AF, AO). However, 3 mo after tamoxifen treatment, the numbers of both $\mathrm{DCX}^{+}$neuroblasts and $\mathrm{GFAP}^{+}{ } \mathrm{MCM}^{+}$neural stem cells were lower in Hes1/3/5/Hey1 mutants than in the controls (Fig. 2AG,AH,AK,AL,AO|. Sox $2^{+}{ }^{+} \mathrm{Ascll}^{+}$neural stem cells also tended to decrease in the mutant SGZ compared with in the controls (Fig. 2AI,AM). Furthermore, BrdU was administered for seven consecutive days to label both transit-amplifying cells and slowly dividing neural stem cells, but the number of $\mathrm{BrdU}^{+}$cells significantly decreased in the mutant SGZ compared with in the controls (Fig. 2AJ,AN, AO). Thus, in adult Hes1/3/5/Hey1 mutant mice, Ascl1dependent neurogenesis increases only transiently but then prematurely ceases due to depletion of neural stem cells. These results suggested that Hes and Hesrelated genes cooperatively inhibit Ascll-induced neurogenesis and regulate the maintenance of neural stem cells in the adult brain.

We also treated these mice with tamoxifen at embryonic day 9.5 and found enhanced expression of proneural 
genes, including Ascl1; accelerated neurogenesis; and premature depletion of virtually all BrdU-incorporating active neural stem cells in the Hes1/3/5/Hey1 mutant mice (Supplemental Fig. S3D-F,H,M-P), whereas the control mice were mostly normal (Supplemental Fig. S3A-C, G,I-L). Thus, Hes and Hes-related genes are required to maintain both embryonic and adult neural stem cells.

\section{Essential roles of Hes genes in maintaining adult neural stem cells}

The above results suggest that following inactivation of Hes and Hes-related genes in the adult brain, all neural stem cells become transit-amplifying cells and neurons, leading to a transient increase in neurogenesis, but then neural stem cells are depleted, which eventually leads to an arrest of neurogenesis. To further confirm this notion, we quantified the label-retaining cells-those representing slowly dividing (or quiescent) neural stem cells-in Hes1/3/5/Hey1 mutant mice that had been injected with tamoxifen $10 \mathrm{~d}$ before. BrdU was given to both Hes1/3/5/Hey1 mutant mice and control mice for 14 consecutive days to label not only transit-amplifying cells but also slowly dividing neural stem cells (Fig. 3A). After $14 \mathrm{~d}$ of BrdU administration $(t=0)$, all dividing cells, including slowly dividing neural stem cells, were labeled by prolonged exposure to $\mathrm{BrdU}$, whereas, $12 \mathrm{~d}$ after BrdU administration $(t=12)$, slowly dividing neural stem cells selectively retained BrdU because the BrdU was diluted out in fast-cycling transit-amplifying cells. In agreement with the above results (Fig. 2), there were significantly more dividing cells in Hes1/3/5/Hey1 mutant mice than in the controls at $t=0$ (Fig. $3 \mathrm{~B}, \mathrm{C}, \mathrm{F})$. At $t=12$, there were numerous label-retaining cells in the control mice (Fig. $3 \mathrm{D}, \mathrm{G})$, whereas the number of $\mathrm{BrdU}^{+}$cells was severely reduced in Hes1/3/5/Hey1 mutant mice (Fig. 3E,G). These control mice had a number of BrdU-incorporating cells similar to that of wild-type control mice (Fig. 3F,G). These results indicate that slowly dividing neural stem cells are severely reduced in number as early as $10 \mathrm{~d}$ after the Hes/ Hey genes are inactivated.

It has been shown that treatment with the antimitotic drug cytosine- $\beta$-D-arabinofuranoside (AraC) kills transitamplifying cells but does not affect slowly dividing or quiescent neural stem cells (Morshead et al. 1994; Doetsch et al. 1999). Thus, while neurogenesis is transiently impaired by AraC treatment, the damaged brains are later reconstituted by slowly dividing or quiescent neural stem cells (Doetsch et al. 1999). We next examined this regeneration process in control and Hes1/3/5/Hey1 mutant mice that had been injected with tamoxifen $10 \mathrm{~d}$ before (Fig. 3H). After $7 \mathrm{~d}$ of AraC treatment $(t=0)$, cells that incorporated BrdU in BrdU pulse-labeling experiments (transit-amplifying cells) and $\mathrm{DCX}^{+}$neuroblasts were mostly missing in both control and Hes1/3/5/Hey1 mutant mice (Fig. 3I,J,M,N,Q). At day $10(t=10)$, however, the $\mathrm{BrdU}^{+}$transit-amplifying cell population in the control brains returned to normal numbers, indicating that neurogenesis had resumed (Fig. 3K,L,Q). In contrast, in the Hes1/3/5/Hey1 mutant brains, BrdU ${ }^{+}$transit-amplify-
A

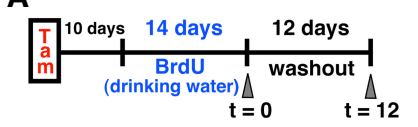

H
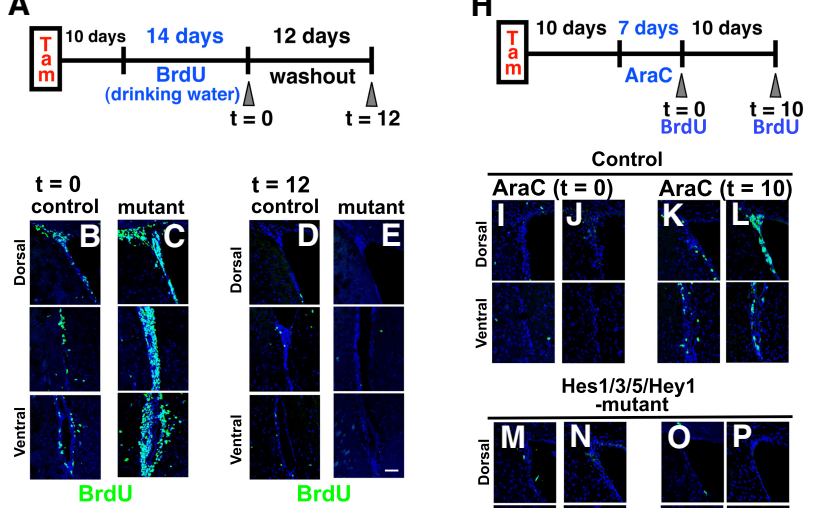

F

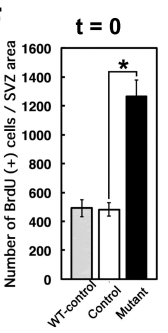

G
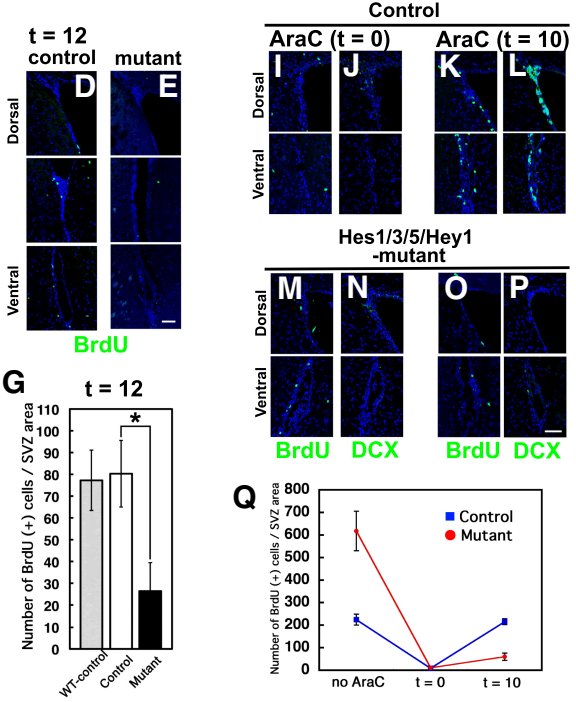

$\underset{\text {-mutant }}{\text { Hes } 1 / 3 / 5 / \text { Hey } 1}$
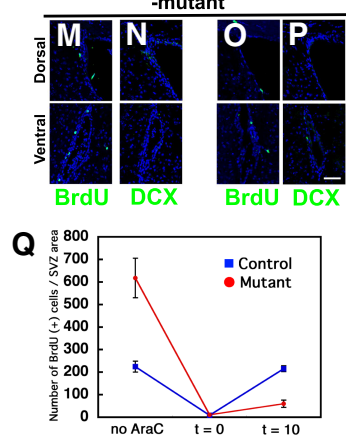

Figure 3. Depletion of slowly dividing neural stem cells and impairment of regeneration after cytosine- $\beta$-D-arabinofuranoside (AraC) treatment in Hes1/3/5/Hey1 mutant adult mouse brains. (A) Experimental design. $(B-E)$ Dividing progenitors $(t=0 ; B, C)$ and slowly dividing cells, ones that retained labeling even after $12 \mathrm{~d}(t=12 ; D, E)$, in the SVZ were labeled with BrdU in control $(B, D)$ and Hes1/3/5/Hey1 mutant $(C, E)$ mice. $(F, G)$ Quantification of the number of BrdU-incorporating cells in the SVZ at $t=0$ and $t=$ 12 after BrdU administration for 14 consecutive days. WT-control $\left(\right.$ Hes ${ }^{+/+} ; \mathrm{Hes}^{+/+}{ }^{+}$Hes $\left.5^{+/+} ; \mathrm{Hey} \mathrm{1}^{+/+}\right)$mice are shown as a reference. $(H)$ Experimental design. $(I-P)$ Coronal sections of the SVZ showing BrdU-incorporating cells soon after the removal of the osmotic $\operatorname{pump}(t=0 ; I J,, M, N)$ and $10 \mathrm{~d}$ after the pump removal $(t=10 ; K, L, O$, $P($ in AraC-treated control $(I-L)$ and AraC-treated Hes1/3/5/Hey1 mutant $(M-P)$ mice. (Q) Quantification of the number of BrdU-incorporating cells in the SVZ. BrdU was administered for $4 \mathrm{~h}$ before sacrifice. $\left(^{*}\right) P<0.05$, Student's $t$-test. Scale bars, $50 \mu \mathrm{m}$.

ing cells did not reappear, and thus neurogenesis had not resumed by $t=10$ (Fig. 3O-Q). This failed resumption was likely due to the lack of slowly dividing or quiescent neural stem cells at this stage in Hes1/3/5/Hey1 mutant mice. These results indicated that Hes/Hey genes are required for neuronal regeneration in AraC-treated brains by maintaining slowly dividing or quiescent neural stem cells.

\section{Sustained Hes1 expression represses Ascl1 expression and inhibits neurogenesis}

We next examined whether sustained Hes1 expression is sufficient for suppression of both Ascll expression and neurogenesis in the adult brain. We generated Rosa26 knock-in mice, in which continuous Hes1 and GFP expression was induced from the Rosa26 locus by Cre expression (Fig. 4A, bottom panel). These mice were 


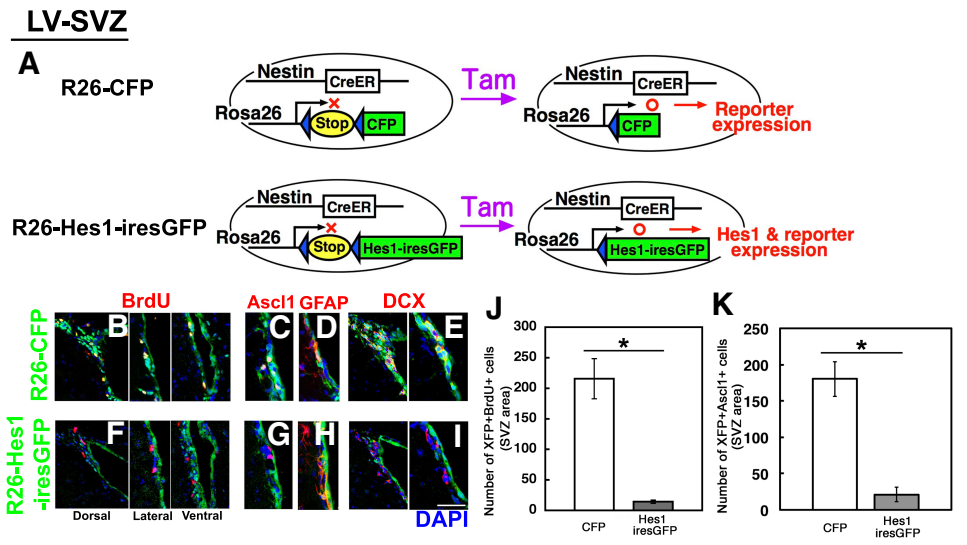

DG-SGZ

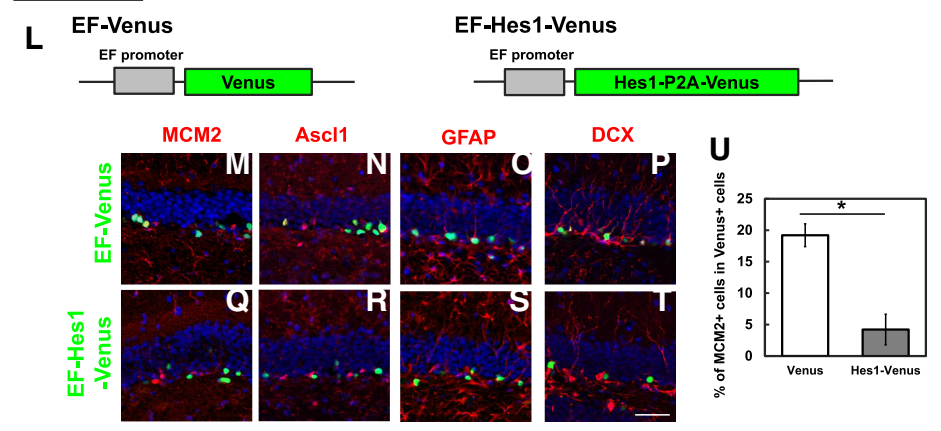

Figure 4. Suppression of Ascll expression and neurogenesis in the adult mouse brain by sustained expression of Hes1. (A) Experimental design. (B-I) Immunohistological analysis of the SVZ of R26-CFP $(B-E)$ and R26-Hes1iresGFP $(F-I)$ mice that had been treated with tamoxifen $1 \mathrm{wk}$ before. BrdU was administered for $2 \mathrm{~h}$ before sacrifice. $(J, K)$ Quantification of BrdU-incorporating $(J)$ and Ascll-expressing $(K)$ cells among CFP- or GFP-labeled cells. $(L)$ Structures of lentiviruses. $(M-T)$ Immunohistological analysis of the SGZ 1 wk after infection with EFVenus virus $(M-P)$ or EF-Hes1-Venus virus $(Q-T)$. $(U)$ Quantification of $\mathrm{MCM}^{+}$cells among virus-infected cells $\left(\right.$ Venus $\left.^{+}\right) .\left(^{*}\right) P<0.05$, Student's $t$-test. Scale bars: $50 \mu \mathrm{m}(B-I) ; 30 \mu \mathrm{m}(M-T)$. crossed with Nes-CreER ${ }^{\mathrm{T} 2}$ mice to induce continuous Hes 1 and GFP expression specifically in neural stem cells by tamoxifen treatment (R26-Hes1-iresGFP mice). As a control, we used Rosa26 knock-in mice, in which only CFP expression was induced from the Rosa26 locus by Cre expression (R26-CFP) (Fig. 4A, top panel). Tamoxifen was applied at 2 mo of age, and brains were examined 1 wk later. In the SVZs of control mice, many CFP-labeled cells incorporated BrdU (Fig. 4B,J). Furthermore, while some of the CFP-labeled cells expressed GFAP, a stem cell marker (Fig. 4D), many of them expressed Ascll or DCX (Fig. 4C,E,K), suggesting that CFP-labeled neural stem cells became active and produced transit-amplifying cells and neuroblasts within $1 \mathrm{wk}$ in control mice. In contrast, in the SVZs of R26-Hes1-iresGFP mice, many GFP-labeled cells appeared, but virtually all of them expressed GFAP (Fig. 4H). Furthermore, very few of the GFP-labeled cells incorporated BrdU (Fig. 4F,J) or coexpressed Ascl1 or DCX (Fig. 4G,I,K). In the hippocampal dentate gyrus of R26-Hes1-iresGFP mice, sustained Hes1 expression did not efficiently occur. Therefore, we used lentivirus to induce sustained Hesl expression (Fig. 4L). Many cells infected with the control virus (EF-Venus) expressed MCM2, Ascl1, GFAP, or DCX (Fig. 4M-P,U), whereas most cells infected with the Hes1 virus (EF-Hes1-Venus) expressed GFAP but not MCM2, Ascl1, or DCX (Fig. 4Q-U). These results indicated that sustained Hes1 expression is sufficient to not only repress Ascll expression but also inhibit neurogenesis, thereby maintaining quiescent neural stem cells in the adult brain.
Optogenetic induction of Ascl1 oscillations activates neural stem cells in the adult brain

The above results suggest that high Hes1 expression and resultant Ascl1 suppression contribute to the maintenance of quiescent neural stem cells in the adult brain, which raised the possibility that inducing Ascll oscillations may activate quiescent neural stem cells and initiate neurogenesis. We tested this possibility by using the previously developed optogenetic Ascl1-inducing system, in which blue light-activated hGAVPO (Wang et al. 2012) induced Ascl1 expression (Supplemental Fig. S4A; Imayoshi et al. 2013). This system was introduced with lentiviruses (hGAVPO-mCherry virus and UAS-Ascll virus) into cultured NS cells that were then illuminated with blue light. Although this system efficiently induced Ascll expression in active NS cells, it only induced low levels of Ascll expression in quiescent NS cells (Supplemental Fig. S4C). In contrast, blue light-activated hGAVPO efficiently induced luciferase expression in quiescent NS cells (data not shown), suggesting that low levels of Ascll protein in a quiescent state was due to its fast degradation (Urbán et al. 2016). Indeed, it was shown previously that BMP signaling decreases Ascll protein stability (Viñals et al. 2004).

Because the Ascl1-E47 fusion protein is more active and stable than Ascl1 (Geoffroy et al. 2009), we next optogenetically induced the Ascll-E47 fusion protein with hGAVPO-mCherry virus and UAS-Ascl1-E47-Venus virus (Supplemental Fig. S4B) and found that the Ascl1-E47 fusion protein was more efficiently induced in quiescent 
NS cells than Ascl1, reaching a level similar to that in active NS cells (Supplemental Fig. S4D). Using this system, we optogenetically induced the expression of Ascl1-E47 fusion protein in cultured quiescent NS cells. It was shown previously that 1 min of blue light exposure at 3 -h intervals induced oscillatory expression, while $1 \mathrm{~min}$ of blue light exposure at 30-min intervals induced sustained expression (Imayoshi et al. 2013). Induction of Ascll oscillations efficiently activated quiescent NS cells to generate $\mathrm{Ki}^{+} 7^{+} \mathrm{DCX}^{-}$cells at day 4 and day 7 (Supplemental Fig. $\mathrm{S} 5 \mathrm{~A}, \mathrm{~B}, \mathrm{D}, \mathrm{F})$. In contrast, induction of sustained Ascl1 expression more efficiently generated $\mathrm{Ki}^{+} 7^{+} \mathrm{DCX}^{+}$and $\mathrm{Ki}^{-} 7^{-} \mathrm{DCX}^{+}$cells at day 4 and day 7 and depleted $\mathrm{Ki}^{+} 7^{+} \mathrm{DCX}^{-}$cells by day 7 (Supplemental Fig. S5A,C, E-G). These results suggest that Ascll oscillations are able to activate cultured quiescent NS cells and maintain active NS cells more efficiently than sustained expression of Ascll.

To induce Ascll oscillations in adult neural stem cells, we next introduced the same lentiviral system into the SGZ of the hippocampal dentate gyrus in adult mouse brains and implanted optic fibers to shine a blue light (Fig. 5A). We used 6-mo-old and 13- to 14-mo-old mice because very few neural stem cells express Ascll at these stages. Light pulses were applied to induce Ascll oscillations with 2.5-h periodicity for 1 or $2 \mathrm{wk}$ (Fig. 5B; Supplemental Fig. S6A-C). After 1 wk of light stimulation, $39.1 \% \pm 8.3 \%$ and $32.8 \% \pm 3.5 \%$ of the cells infected with both hGAVPO-mCherry and UAS-Ascl1-E47-Venus viruses expressed $\mathrm{Ki} 67$ and Ascl1, respectively, in 6-moold mice (Fig. 5D-K, $\mathrm{D}^{\prime}-\mathrm{K}^{\prime}, \mathrm{M}, \mathrm{N}$ ). Furthermore, $15.6 \% \pm$ $2.6 \%$ of the double-infected cells were positive for DCX (Fig. 5C-E, $\mathrm{C}^{\prime}-\mathrm{E}^{\prime}, \mathrm{L}$ ), suggesting that neurogenesis was activated. In contrast, virtually none of the cells infected with hGAVPO-mCherry virus alone expressed Ascll or Ki67 (Fig. 5M,N), and most of these single-infected cells were negative for DCX (Fig. 5L). Similarly, neurogenesis was activated in cells infected with both hGAVPO-mCherry and
UAS-Ascl1-E47-Venus viruses, but not in single-infected cells, in 13- to 14-mo-old mice after 1 wk of light stimulation (Supplemental Fig. S6D-L, D'-L'). These findings suggest that optogenetic induction of Ascll oscillations efficiently activated quiescent neural stem cells to initiate neurogenesis in adult mice.

To examine the long-term effects of Ascll oscillations, we continued light stimulation for a longer period. However, after 2 wk of light stimulation, significantly fewer double-infected cells expressed Ascll (Supplemental Fig. S6M-Q), indicating that the double-infected cells initially expressed Ascll by responding to light illumination, but most of them lost this ability within $2 \mathrm{wk}$. We also found that when sustained Ascll expression was optogenetically induced, there were very few double-infected cells that expressed Ascll even after $1 \mathrm{wk}$ of light stimulation (data not shown). Furthermore, we noticed that cultured NS cells gradually lost their light responsiveness for Ascll expression (data not shown). Thus, it is likely that the hGAVPO-UAS system loses light responsiveness over time for unknown reasons, and therefore we were not able to examine longer effects of Ascll oscillations on neural stem cells.

\section{Hes5 promoter-driven Ascl1 expression activates quiescent neural stem cells in the adult brain}

To overcome the above difficulty, we tried an alternative approach to induce oscillatory Ascl1-E47 expression. It was reported that the Hes5 promoter can induce gene expression in neural stem cells (Lugert et al. 2010). We confirmed that injecting a lentivirus carrying Hes5 promoterdriven Venus cDNA successfully induced Venus expression in $\mathrm{GFAP}^{+}$;Sox $2^{+}$neural stem cells in the SGZ of the adult mouse hippocampus (Fig. 6A). Because the Hes5 promoter also induced oscillatory expression (Supplemental Fig. S7A), we used it to induce expression of the Ascl1E47 fusion protein in cultured quiescent NS cells prepared

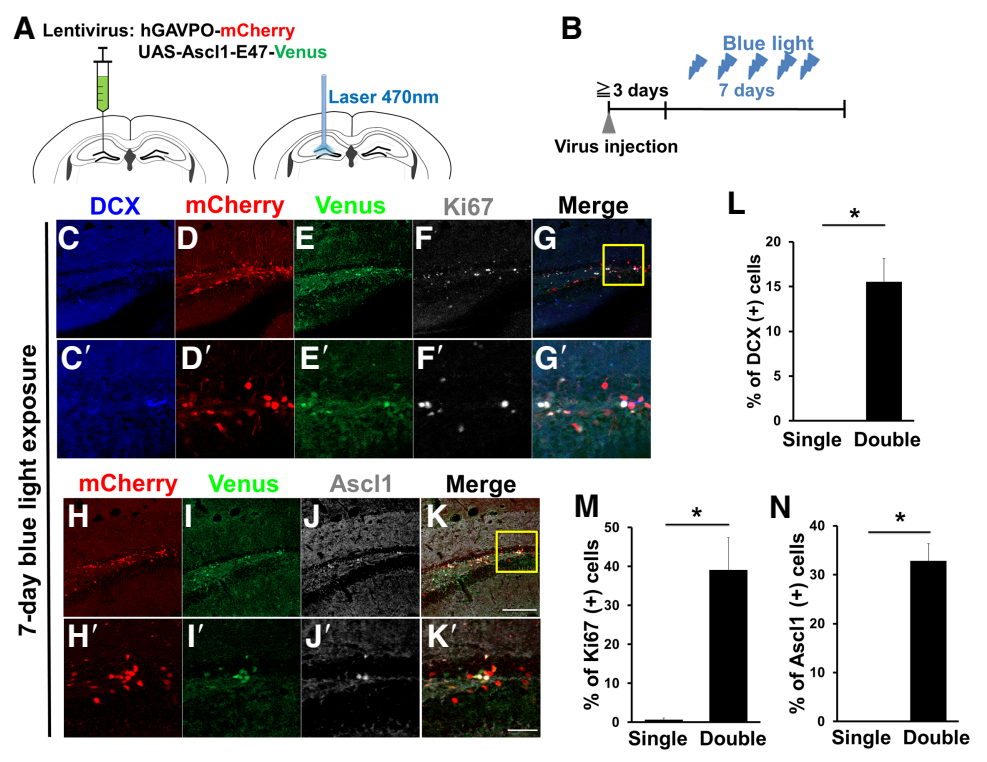

Figure 5. Optogenetic induction of Ascll oscillations in neural stem cells in the adult mouse brain 16 mo old; $n=$ 3). $(A, B)$ Experimental design. (A) After virus injection (left), optic fiber connected to Optoflash was implanted to illuminate with blue light (right). (B) Ascll oscillations with 2.5 -h periodicity were induced, and brain sections were examined after $7 \mathrm{~d}$ of illumination. $(C-K)$ Immunohistological analysis of cells in the adult mouse hippocampal dentate gyrus infected with hGAVPO-mCherry virus and UAS-Ascl1-E47-Venus virus. Boxed regions in $G$ and $K$ are enlarged in $C^{\prime}-G^{\prime}$ and $H^{\prime}-K^{\prime}$, respectively. $(L-N)$ Quantification of marker expression in cells infected with both hGAVPO-mCherry virus and UAS-Ascl1E47-Venus virus (double) or with hGAVPO-mCherry virus alone (single). $\left(^{*}\right) P<0.05$, Student's $t$-test. Scale bars: $100 \mu \mathrm{m}(C-K) ; 30 \mu \mathrm{m}\left(C^{\prime}-K^{\prime}\right)$. 
from Delta-like1 (Dll1) reporter mice (Shimojo et al. 2016). Dll1 expression is directly controlled by Ascll (Castro et al. 2006). Therefore, Dll1 expression oscillates in active neural stem cells with oscillating Ascll expression, while it is sustained in differentiating neurons with sustained Ascll expression (Shimojo et al. 2008, 2016). There was no Dll1 reporter expression in NS cells when they were maintained in a quiescent state, but oscillatory Dll1 reporter expression occurred in NS cells when Hes5 promoter-driven Ascl1-E47 expression was induced (Supplemental Fig. S7B,C), suggesting that the Hes5 promoter successfully induced oscillatory Ascl1-E47 expression in quiescent neural stem cells.

We also examined the effects of Hes 5 promoter-driven Ascl1-E47 expression on in vitro NS cell cultures. Infection with a lentivirus that induced Ascl1-E47 expression under the control of the Hes 5 promoter efficiently activated cultured NS cells $\left(\mathrm{Ki}_{6} 7^{+} \mathrm{DCX}^{-}\right)$at day 4 and day 7 (Supplemental Fig. S7D,E), like the optogenetic induction of Ascl1-E47 oscillations. Infection with this virus also generated $\mathrm{Ki}^{+} 7^{+} \mathrm{DCX}^{+}$and $\mathrm{Ki} 67^{-} \mathrm{DCX}^{+}$cells at day 4 and day 7 (Supplemental Fig. S7D,F). These results indicated that
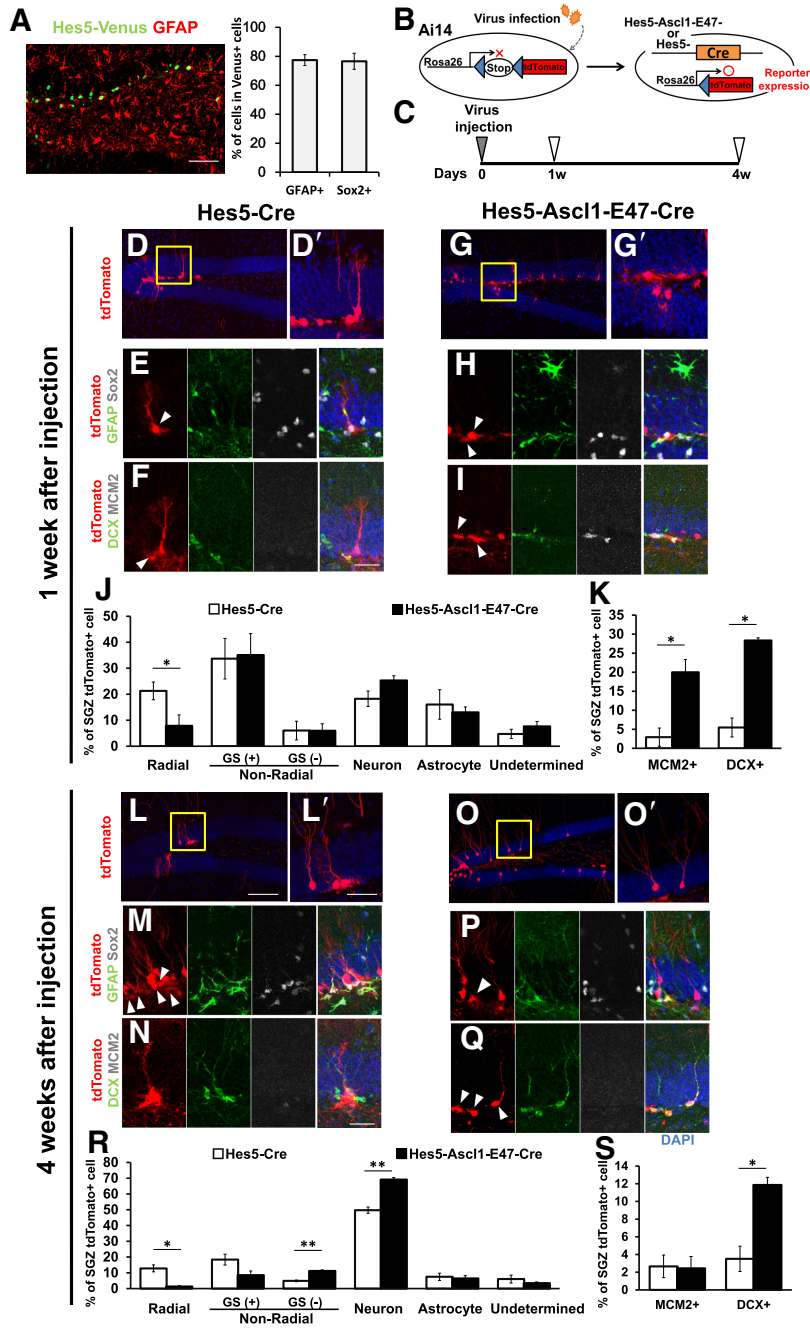

Hes5 promoter-driven Ascl1-E47 expression is able to activate quiescent NS cells, which initiate proliferation and neuronal differentiation.

To analyze the in vivo effects of Hes 5 promoter-driven Ascl1-E47 expression on adult neural stem cells, lentivirus-inducing Cre recombinase as well as Ascll-E47 expression under the control of the Hes5 promoter (Hes5Ascl1-E47-Cre virus) were prepared. As a control, we used lentivirus-inducing Cre recombinase only under the control of the Hes5 promoter (Hes5-Cre virus). These viruses were injected into the SGZs of the adult Ai14 mice, in which Cre recombinase labels not only infected cells but also their progeny with tdTomato (Fig. 6B; Madisen et al. 2010). We used Ai14 mice at 5-8 mo of age for the analysis because neurogenesis significantly decreases at this stage in the SGZ (Imayoshi et al. 2008a; Encinas et al. 2011). Brain sections were examined 1 and $4 \mathrm{wk}$ later (Fig. 6C). One week after the Hes5-Cre control virus injection, many of the virus-infected cells $\left(\right.$ tdTomato $\left.^{+}\right)$had a radial morphology and coexpressed GFAP and Sox 2 (Fig. 6D, $\mathrm{D}^{\prime}, \mathrm{E}, \mathrm{J}$, open bar), and very few of them expressed the cell cycle marker MCM2 (Fig. 6F,K, open bar), suggesting that these virus-infected cells were mostly quiescent neural stem cells. In contrast, 1 wk after the Hes5-Ascl1-E47-

Figure 6. Induction of Ascl1-E47 expression by the Hes5 promoter in the adult mouse brain $(5-8$ mo old; $n=3)$. (A) Lentivirus carrying Hes5 promoter-driven Venus cDNA was injected into the hippocampal dentate gyrus of adult mice, and brains were examined $4 \mathrm{~d}$ later. $(B, C)$ Experimental design. $(D-I)$ Either Hes5Cre virus $(D-F)$ or Hes5-Ascl1-E47-Cre virus $(G-I)$ was injected into the hippocampal dentate gyrus of Ail4 mice, and brains were examined $1 \mathrm{wk}$ later. Boxed regions in $D$ and $G$ are enlarged in $D^{\prime}$ and $G^{\prime}$. (E) When the Hes5-Cre virus was infected, many tdTomato $^{+}$cells had a radial morphology and coexpressed GFAP and Sox2 (arrowhead). (F) Some coexpressed DCX, but MCM2 was mostly negative (arrowhead). $(H, I)$ When the Hes5Ascl1-E47-Cre virus was infected, many tdTomato ${ }^{+}$cells had a nonradial morphology and coexpressed GFAP and Sox $2(H$, arrowheads) or DCX and MCM2 (I, arrowheads). (J) Quantification of the indicated types of tdTomato ${ }^{+}$cells in the SGZ. Radial cells are $\mathrm{GFAP}^{+} ; \mathrm{Sox}^{+}$neural stem cells. Nonradial cells are either $\mathrm{GFAP}^{+} / \mathrm{Sox}^{+}$-activated neural stem cells $\left(\mathrm{GS}^{+}\right)$or $\mathrm{GFAP}^{-}$;Sox $2^{-}$ transit-amplifying cells $\left(\mathrm{GS}^{-}\right)$. Neurons and astrocytes were identified based on morphology and markers $\left(\mathrm{DCX}^{+}\right.$and/or $\mathrm{NeuN}^{+}$for neurons and $\mathrm{GFAP}^{+}$for astrocytes). There were very few $\mathrm{NG}^{+}$oligodendrocytes under this condition. $(K)$ Quantification of the indicated marker expressions in tdTomato $^{+}$cells. $(L-Q)$ Either Hes5-Cre virus $(L-N)$ or Hes5-Ascl1-E47-Cre virus $(O-Q)$ was injected into the hippocampal dentate gyrus of Ail4 mice, and brains were examined 4 wk later. Boxed regions in $L$ and $O$ are enlarged in $L^{\prime}$ and $O^{\prime} .(M, P, Q)$ tdTomato ${ }^{+}$cells coexpressing GFAP and Sox $2(M, P)$ or DCX $(Q)$ are indicated by arrowheads. $(R)$ Proportions of the indicated types of tdTomato ${ }^{+}$cells in the SGZ and granule cell layer were quantified, as in $J$. $(S)$ Quantification of the indicated marker expressions in tdTomato ${ }^{+}$cells. $(J, K, R$, $S)$ Open and closed bars represent cells infected with Hes5-Cre virus and Hes5-Ascl1-E47-Cre virus, respectively, in all graphs. $\left({ }^{*}\right) P$ $<0.05,\left(^{* *}\right) P<0.01$, Student's $t$-test. Scale bars: $50 \mu \mathrm{m}(A, D, G, L$, $O) ; 20 \mu \mathrm{m}\left(D^{\prime}, E, F, G^{\prime}, H, I, L^{\prime}, M, N, O^{\prime}, P, Q\right)$. 
Cre virus injection, many virus-infected cells (tdTomato ${ }^{+}$) lost a radial morphology and down-regulated GFAP and Sox2 expression (Fig. 6G, $\mathrm{G}^{\prime}, \mathrm{H}, \mathrm{J}$, closed bar). Furthermore, $20.0 \% \pm 3.3 \%$ of the virus-infected cells expressed the cell cycle marker MCM2 (Fig. 6I [arrowheads], K [closed bar]), suggesting that many neural stem cells were activated by the Hes5-Ascl1-E47-Cre virus within $1 \mathrm{wk}$, as observed for optogenetic induction of Ascl1-E47 oscillations. There were also more $\mathrm{DCX}^{+}$neuroblasts at this stage (Fig. 6I, $\mathrm{K}$, closed bar). Four weeks after the Hes5-Cre control virus injection, some tdTomato ${ }^{+}$cells still had a radial morphology (Fig. 6L, L', R, open bar) and were positive for GFAP and Sox2 but mostly negative for MCM2 (Fig. 6M,N,S, open bar), suggesting that these cells were quiescent neural stem cells. At this stage, there were only some $\mathrm{DCX}^{+}$virus-infected neuroblasts (Fig. 6N,S, open bar), suggesting that the neurogenic activity of the control virus-infected neural stem cells remained low. In contrast, 4 wk after the Hes5-Ascl1-E47-Cre virus injection, the majority of the virus-infected cells (tdTomato ${ }^{+}$) differentiated into neurons (Fig. 6O, $\mathrm{O}^{\prime}, \mathrm{R}$, closed bar). Furthermore, there were fewer $\mathrm{GFAP}^{+}$; Sox $2^{+}$virus-infected cells with a nonradial morphology (Fig. 6P, arrowhead), and $11.9 \% \pm 0.9 \%$ of the virus-infected cells expressed DCX (Fig. 6Q [arrowheads], $S$ [closed bar]), suggesting that the neurogenic activity of the virus-infected cells was maintained until this stage. Under this condition, only a minor population of the virus-infected cells differentiated into astrocytes or oligodendrocytes (Fig. 6R). These results suggest that Hes5 promoter-driven Ascl1-E47 expression activates neurogenesis and maintains neurogenic activity for a longer term in the adult brain.

\section{Discussion}

\section{High levels of Hes1 expression regulate quiescent neural stem cells}

The molecular nature of differences between the active and quiescent states of stem cells is not fully understood. Notch signaling is reportedly required to maintain both active and quiescent neural stem cells (Nyfeler et al. 2005; Ables et al. 2010; Ehm et al. 2010; Imayoshi et al. 2010; Veeraraghavalu et al. 2010), but how the same signaling pathway regulates such different states of neural stem cells remained to be determined. Here, we found that expression of the Notch signaling effector Hes 1 oscillates in active neural stem cells but is high in quiescent neural stem cells (Fig. 7). Ascll expression also oscillates in active neural stem cells due to periodic repression by Hes1, while it is suppressed in quiescent neural stem cells by high Hes1 expression (Fig. 7). Ascl1 plays an important role in not only neuronal differentiation but also proliferation of neural stem cells, and these opposing functions are controlled by its sustained versus oscillatory expression: Oscillatory Ascll expression activates proliferation of neural stem cells, while sustained Ascl1 expression induces neuronal differentiation (Castro et al. 2011; Imayoshi et al. 2013). Furthermore, it was reported that Ascl1 is absolutely required for activation of

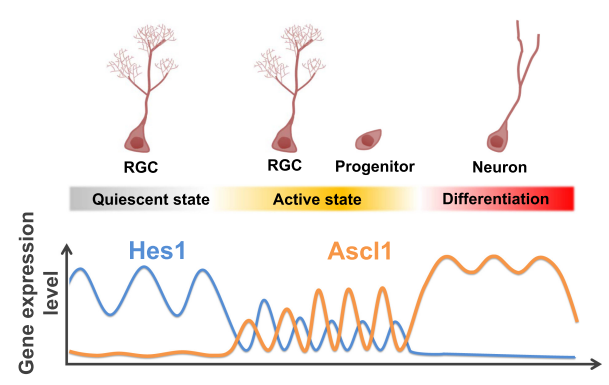

Figure 7. Expression dynamics of Hes1 and Ascll in quiescent and active neural stem cells and differentiating neurons. (RGC) Radial glia-like neural stem cell.

quiescent neural stem cells (Andersen et al. 2014). Together, these findings suggest that high Hes1 expression and the resultant suppression of Ascll expression may contribute to the quiescent state of neural stem cells in the adult brain (Fig. 7). Indeed, inactivation of Hes1 and its related genes leads to Ascll expression and activation of quiescent neural stem cells, enhancing neurogenesis. In such activated neural stem cells, the function of Ascll could be oscillatory because the expression of Id1, which antagonizes Ascl1, is high (Nam and Benezra 2009) and could be oscillatory (William et al. 2007).

The detailed mechanism by which high levels of Hes 1 are maintained in quiescent neural stem cells remains to be determined. Oscillatory expression of Hes1 is controlled by negative feedback: Hes1 represses its own expression by directly binding to its promoter (Hirata et al. 2002). It was reported that high levels of Idl interact with Hes1 and inhibit its negative feedback, thereby upregulating Hes1 expression (Bai et al. 2007; Boareto et al. 2017). Id1 expression is induced by BMP signaling (Miyazono and Miyazawa 2002), an essential pathway for the maintenance of quiescent neural stem cells (Mira et al. 2010). These results suggest that the BMP-Id-Hes axis may be the major pathway for suppressing Ascll and maintaining quiescent neural stem cells in the adult brain.

\section{High Hes1 expression and quiescence}

High levels of Hes1 are also observed in other types of quiescent cells. For example, high levels of Hes1 and the resultant suppression of Ascl1 and other proneural genes occur in the boundary regions of the embryonic brain, such as the isthmus, floor plate, and roof plate (Baek et al. 2006). In these regions, cells are mostly quiescent, suggesting that Hes1 and proneural factor oscillations may be important for cell cycle progression. Another example is the high levels of Hes 1 found in quiescent hematopoietic stem/progenitor cells and quiescent muscle satellite cells (Yu et al. 2006; Mourikis et al. 2012). Furthermore, overexpression of Hes1 inhibits proliferation of hematopoietic stem/progenitor cells (Yu et al. 2006), suggesting that a high level of Hes1 is a common feature of cell quiescence. Similarly, it was reported that Hes1 is highly expressed by human fibroblasts when they enter quiescence due to serum deprivation or contact inhibition 
(Sang et al. 2008). Interestingly, these quiescent fibroblasts lost their ability to resume proliferation and entered senescence when Hes1 was knocked down, whereas high sustained Hes1 was sufficient to prevent these cells from entering senescence associated with prolonged cell cycle arrest (Sang et al. 2008). Hes1 also plays an important role in contact inhibition of proliferation in preadipocytes (Noda et al. 2011). Thus, high levels of Hes1 expression may be a general feature to prevent senescence and maintain quiescence of many cell types, including stem cells.

\section{Ascl1 oscillations regulate active neural stem cells}

Ascl1 is expressed in an oscillatory manner by active neural stem cells, and we found that inducing Ascl1 oscillations activates quiescent neural stem cells to generate new neurons in the adult brain. In both in vitro and in vivo experiments, optogenetic and Hes5 promoter-driven induction of Ascl1 oscillations activated neural stem cells to generate new neurons. When Hes5 promoter-driven Ascl1 oscillations were induced, the neurogenic activity was maintained for $\sim 4 \mathrm{wk}$, while it mostly declined in controls.

Ascl1 is required to generate both neurons and oligodendrocytes in the postnatal brain (Parras et al. 2004; Andersen et al. 2014). However, CAG promoter-induced overexpression of Ascl1 in adult hippocampal neural stem cells leads to exclusive generation of oligodendrocytes at the expense of neurons (Jessberger et al. 2008), although these neural stem cells normally generate neurons after Ascl1 expression (Pilz et al. 2018). In contrast, Hes5 promoter-driven induction of Ascl1 mostly generated neurons and virtually no oligodendrocytes in the adult hippocampus. The mechanism underlying these differences remains to be analyzed. One possibility concerns their different expression patterns: The Hes 5 promoter is specific to neural stem cells and is therefore suppressed in differentiating cells, while the CAG promoter is active in both neural stem cells and differentiating cells. Ascll expression is normally down-regulated in differentiating neurons (Lo et al. 1991), and CAG promoter-induced continuous expression of Ascll might block neuronal differentiation and redirect neural stem cells toward the oligodendrocyte lineage at the expense of neurons. Another possibility is their different expression levels: The CAG promoter exhibits stronger activity than the Hes5 promoter, and high sustained Ascll expression might favor the oligodendrocyte lineage over the neuronal lineage. Alternatively, it is possible that Ascl1 functions together with Olig1 and Olig2, essential factors for oligodendrogenesis, whereas the Ascl1-E47 heterodimer does not. Further analyses are required to understand the mechanism by which Ascll differentially regulates specification of neurons and oligodendrocytes.

We demonstrated that the Hes5 promoter-driven Ascll expression system offers an efficient way to activate quiescent neural stem cells to induce neurogenesis in the adult brain. This method may be useful to manipulate endogenous stem cells for therapeutic purposes in patients with various brain disorders as an alternative to trans- planting exogenous cells (Gaspard et al. 2008; Falkner et al. 2016).

\section{Materials and methods}

Transgenic mice

Hes1 flox mice, Hes3-null mice, Hes5-null mice, Nes-CreER ${ }^{\mathrm{T} 2}$ mice, Nestin-mCherry mice, Luc2-Hes1 mice, and Luc2-Ascl1 mice were generated before (Hatakeyama et al. 2004; Kokubo et al. 2005; Imayoshi et al. 2006, 2008b, 2013; Furutachi et al. 2015). Hey1-null mice and Ail4 mice were obtained from Yumiko Saga and Jackson Laboratory, respectively.

\section{Tissue preparation and immunochemistry}

Tissue preparation and immunochemical analyses were performed as described previously (Shimojo et al. 2016). The following primary antibodies (final dilution and source) were used: rabbit anti-Hes1 (1:500) (Kobayashi et al. 2009), mouse anti-ßIIItubulin (1:500; Babco), rat anti-BrdU (1:50; Oxford Biotech), goat antidoublecortin (DCX; 1:200; Santa Cruz Biotechnology), mouse anti-GFAP (1:200; Sigma), rabbit anti-GFAP (1:200; Sigma), mouse antimammalian achaete-schute homolog 1 (1:20; BD Pharmingen), mouse anti-Nestin (1:200; BD Pharmingen), rabbit antiMCM2 (1:500; Abcam), mouse anti-cyclinD1 (1:200; Santa Cruz Biotechnology), goat anti-Sox2 (1:500; R\&D Systems), rat antiGFP (1:500; Nacalai Tesque), chicken anti-GFP (1:500; Abcam), and mouse anti-Ki67 (1:50; BD Biosciences).

\section{Quantification of labeled cells and statistical analysis}

The lateral SVZs and SGZs of more than three adult mice were analyzed in each experiment. A minimum of 10 coronal sections throughout the anterior-posterior extent was assessed for each animal. Stained cells were counted and expressed as the number of cells per $5 \mathrm{~mm}$ along the SVG or per square millimeter of the SGZ for each image. Student's $t$-test (one-tailed) was performed to calculate $P$-values.

\section{Time-lapse imaging of NS cultures and brain slices}

Time-lapse imaging of NS cultures and brain slices was performed as described previously (Imayoshi et al. 2013). For slice cultures, coronal brain slices (150- $\mu \mathrm{m}$ thickness) were transferred into cell culture inserts (Merck) on a glass-base dish with $135 \mathrm{mM}$ $\mathrm{NaCl}_{2}, 5 \mathrm{mM} \mathrm{KCl}, 10 \mathrm{mM}$ HEPES, $1 \mathrm{mM} \mathrm{CaCl}_{2}$, and $1 \mathrm{mM} \mathrm{MgCl}_{2}$ bubbled with $100 \% \mathrm{O}_{2}$ for $30 \mathrm{~min}$ at room temperature. Slices were immersed in type Ia collagen (Cellmatrix) diluted with slice culture medium (135 $\mathrm{mM} \mathrm{NaCl}_{2}, 5 \mathrm{mM} \mathrm{KCl}, 10 \mathrm{mM}$ HEPES, $1 \mathrm{mM} \mathrm{CaCl}_{2}, 1 \mathrm{mM} \mathrm{MgCl}_{2}, 5 \%$ horse serum, $5 \%$ fetal bovine serum) and neutralizing buffer at room temperature. After $10 \mathrm{~min}$ of incubation at $37^{\circ} \mathrm{C}$ in $5 \% \mathrm{CO}_{2}$ and $80 \% \mathrm{O}_{2}$, slices were cultured at $37^{\circ} \mathrm{C}$ in slice culture medium containing $1 \mathrm{mM}$ luciferin. After $6 \mathrm{~h}$, the dish was placed on a stage of an inverted microscope and maintained at $37^{\circ} \mathrm{C}$ in $5 \% \mathrm{CO}_{2}$ and $80 \% \mathrm{O}_{2}$. Bioluminescence was acquired using a CCD camera, as described above.

\section{Generation of R26-Hes1-iresGFP mice}

Rosa26-loxP-stop-loxP-Hes1-iresEGFP knock-in embryonic stem cells (Kobayashi et al. 2009) were used to establish the mouse line, which was crossed with Nes-CreER ${ }^{\mathrm{T} 2}$ mice. 
Tamoxifen treatment of mice

For activation of $\mathrm{CreER}^{\mathrm{T} 2}, 10 \mathrm{mg}$ of tamoxifen was administered orally to 2-mo-old mice once per day for four consecutive days. For controls, Rosa26-loxP-stop-loxP-CFP mice (Srinivas et al. 2001) were crossed with Nes-CreER ${ }^{\mathrm{T} 2}$ mice.

\section{BrdU administration and AraC infusion}

BrdU administration and AraC infusions were performed as described previously (Imayoshi et al. 2010).

\section{Light stimulation in NS cell cultures by the hGAVPO system}

Lentivirus was produced as described previously (Imayoshi et al. 2013). Blue light was delivered by LEDB-SBOXH (OptoCode) at 60 $\mathrm{\mu mol} / \mathrm{m}^{2} / \mathrm{sec}$ for $1 \mathrm{~min}$ with 3 -h intervals for oscillatory expression and for $1 \mathrm{~min}$ with 30-min intervals for sustained expression as described previously (Imayoshi et al. 2013; Isomura et al. 2017).

Lentiviral infection of adult mouse brain and light illumination with optic fibers

The coding sequence for codon-optimized Cre (iCre) or Ascl1E47-P2A-iCre was subcloned into CSII-1.6-kb pHes5-MCS plasmid for lentivirus production. For optical controls of Ascl1 expression, hGAVPO-mCherry and UAS-Ascl1-E47-Venus viruses were applied. Viruses were delivered stereotactically into the dentate gyrus with the following coordinates: anteroposterior $=$ $-2 \mathrm{~mm}$ from bregma; lateral $= \pm 1.5 \mathrm{~mm}$; and ventral $=2.2 \mathrm{~mm}$. Optic fiber connected with Optoflash (Bio Research Center Co., Ltd.) was implanted at the same injection sites immediately after viral injection with a dorsal-ventral depth of $1.6 \mathrm{~mm}$ from the skull. The light illumination condition was empirically determined because the light intensity of Optoflash is much weaker than OptoCode. For achieving oscillatory expression (2.5-h periodicity), blue light $(470 \mathrm{~nm}$ ) was delivered (one cycle consisted of 10 repeats of $2 \mathrm{~min}$ on at 5 -min intervals followed by $80 \mathrm{~min}$ off). One week or 2 wk later, brain sections were immunohistologically examined.

\section{Acknowledgments}

We thank Yumiko Saga for Hey1-null mice, Hongkui Zeng for Ail4 mice, and Hitoshi Miyachi, Hiroyuki Okuno, and Kohei Jino for technical help. This work was supported by Core Research for Evolutional Science and Technology (CREST) (JPMJCR12W2 to R.K., and JPMJCR1752 to I.I.), Grant-in-Aid for Scientific Research on Innovative Areas (16H06480 to R.K., and 16H06529 to I.I.), and Grant-in-Aid for Scientific Research (B) (18H02449 to I.I.) from the Ministry of Education, Culture, Sports, Science, and Technology (MEXT), Japan, and AMEDCREST (JP18gm1110002 to R.K.) and the Program for Technological Innovation of Regenerative Medicine (JP18bm0704020 to I.I.) from the Japan Agency for Medical Research and Development.

Author contributions: R.S., I.I., and Y.H. conducted the experiments. R.S., I.I., Y.H., and R.K. designed the experiments. R.S., I.I., and R.K. wrote the manuscript.

\section{References}

Ables JL, Decarolis NA, Johnson MA, Rivera PD, Gao Z, Cooper DC, Radtke F, Hsieh J, Eisch AJ. 2010. Notch1 is required for maintenance of the reservoir of adult hippocampal stem cells.
I Neurosci 30: 10484-10492. doi:10.1523/JNEUROSCI.472109.2010

Alvarez-Buylla A, García-Verdugo JM, Tramontin AD. 2001. A unified hypothesis on the lineage of neural stem cells. Nat Rev Neurosci 2: 287-293. doi:10.1038/35067582

Andersen J, Urbán N, Achimastou A, Ito A, Simic M, Ullom K, Martynoga B, Lebel M, Göritz C, Frisén J, et al. 2014. A transcriptional mechanism integrating inputs from extracellular signals to activate hippocampal stem cells. Neuron 83: 1085-1097. doi:10.1016/j.neuron.2014.08.004

Baek JH, Hatakeyama J, Sakamoto S, Ohtsuka T, Kageyama R. 2006. Persistent and high levels of Hes1 expression regulate boundary formation in the developing central nervous system. Development 133: 2467-2476. doi:10.1242/dev.02403

Bai G, Sheng N, Bian W, Xie Z, Yokota Y, Benezra R, Kageyama R, Guillemot F, Jing N. 2007. Id sustains Hes1 expression to inhibit precocious neurogenesis by releasing negative autoregulation of Hes1. Dev Cell 13: 283-297. doi:10.1016/j.devcel .2007 .05 .014

Boareto M, Iber D, Taylor V. 2017. Differential interactions between Notch and ID factors control neurogenesis by modulating Hes factor autoregulation. Development 144: 3465-3474. doi:10.1242/dev.152520

Bonaguidi MA, Wheeler MA, Shapiro JS, Stadel RP, Sun GJ, Ming G, Song H. 2011. In vivo clonal analysis reveals self-renewing and multipotent adult neural stem cell characteristics. Cell 145: 1142-1155. doi:10.1016/j.cell.2011.05.024

Castro DS, Skowronska-Krawczyk D, Armant O, Donaldson IJ, Parras C, Hunt C, Critchley JA, Nguyen L, Gossler A, Göttgens B, et al. 2006. Proneural bHLH and Brn proteins coregulate a neurogenic program through cooperative binding to a conserved DNA motif. Dev Cell 11: 831-844. doi:10.1016/j .devcel.2006.10.006

Castro DS, Martynoga B, Parras C, Ramesh V, Pacary E, Johnston C, Drechsel D, Lebel-Potter M, Garcia LG, Hunt C, et al. 2011. A novel function of the proneural factor Ascll in progenitor proliferation identified by genome-wide characterization of its targets. Genes Dev 25: 930-945. doi:10.1101/gad.627811

Doetsch F. 2003. The glial identity of neural stem cells. Nat Neurosci 6: 1127-1134. doi:10.1038/nn1144

Doetsch F, Caillé I, Lim DA, Garcia-Verdugo JM, Alvarez-Buylla A. 1999. Subventricular zone astrocytes are neural stem cells in the adult mammalian brain. Cell 97: 703-716. doi:10.1016/ S0092-8674|00|80783-7

Ehm O, Göritz C, Covic M, Schäffner I, Schwarz TJ, Karaca E, Kempkes B, Kremmer E, Pfrieger FW, Espinosa L, et al. 2010. $\mathrm{RBPJ}$ (-dependent signaling is essential for long-term maintenance of neural stem cells in the adult hippocampus. J Neurosci 30: 13794-13807. doi:10.1523/JNEUROSCI.1567-10.2010

Encinas JM, Michurina TV, Peunova N, Park J-H, Tordo J, Peterson DA, Fishell G, Koulakov A, Enikolopov G. 2011. Divisioncoupled astrocytic differentiation and age-related depletion of neural stem cells in the adult hippocampus. Cell Stem Cell 8: 566-579. doi:10.1016/j.stem.2011.03.010

Falkner S, Grade S, Dimou L, Conzelmann K-K, Bonhoeffer T, Götz M, Hübener M. 2016. Transplanted embryonic neurons integrate into adult neocortical circuits. Nature 539: 248253. doi:10.1038/nature 20113

Furutachi S, Miya H, Watanabe T, Kawai H, Yamasaki N, Harada Y, Imayoshi I, Nelson M, Nakayama KI, Hirabayashi Y, et al. 2015. Slowly dividing neural progenitors are an embryonic origin of adult neural stem cells. Nat Neurosci 18: 657-665. doi:10.1038/nn.3989

Gaspard N, Bouschet T, Hourez R, Dimidschstein J, Naeije G, van den Ameele I, Espuny-Camacho I, Herpoel A, Passante L, 
Schiffmann SN, et al. 2008. An intrinsic mechanism of corticogenesis from embryonic stem cells. Nature 455: 351-357. doi:10.1038/nature07287

Geoffroy CG, Critchley JA, Castro DS, Ramelli S, Barraclough C, Descombes P, Guillemot F, Raineteal O. 2009. Engineering of dominant active basic helix-loop-helix proteins that are resistant to negative regulation by postnatal central nervous system antineurogenic cues. Stem Cells 27: 847-856. doi:10 $.1002 /$ stem. 17

Götz M, Huttner WB. 2005. The cell biology of neurogenesis. Nat Rev Mol Cell Biol 6: 777-788. doi:10.1038/nrm1739

Hatakeyama J, Bessho Y, Katoh K, Ookawara S, Fujioka M, Guillemot F, Kageyama R. 2004. Hes genes regulate size, shape and histogenesis of the nervous system by control of the timing of neural stem cell differentiation. Development 131: 55395545. doi:10.1242/dev.01436

Hirata H, Yoshiura S, Ohtsuka T, Bessho Y, Harada T, Yoshikawa K, Kageyama R. 2002. Oscillatory expression of the bHLH factor Hes1 regulated by a negative feedback loop. Science 298: 840-843. doi:10.1126/science. 1074560

Imayoshi I, Ohtsuka T, Metzger D, Chambon P, Kageyama R. 2006. Temporal regulation of Cre recombinase activity in neural stem cells. Genesis 44: 233-238. doi:10.1002/dvg.20212

Imayoshi I, Sakamoto M, Ohtsuka T, Takao K, Miyakawa T, Yamaguchi M, Mori K, Ikeda T, Itohara S, Kageyama R. 2008a. Roles of continuous neurogenesis in the structural and functional integrity of the adult forebrain. Nat Neurosci 11: 1153-1161. doi:10.1038/nn.2185

Imayoshi I, Shimogori T, Ohtsuka T, Kageyama R. 2008b. Hes genes and neurogenin regulate non-neural versus neural fate specification in the dorsal telencephalic midline. Development 135: 2531-2541. doi:10.1242/dev.021535

Imayoshi I, Sakamoto M, Yamaguchi M, Mori K, Kageyama R. 2010. Essential roles of Notch signaling in maintenance of neural stem cells in the developing and adult brains. I Neurosci 30: 3489-3498. doi:10.1523/JNEUROSCI.4987-09.2010

Imayoshi I, Isomura A, Harima Y, Kawaguchi K, Kori H, Miyachi H, Fujiwara TK, Ishidate F, Kageyama R. 2013. Oscillatory control of factors determining multipotency and fate in mouse neural progenitors. Science 342: 1203-1208. doi:10.1126/sci ence. 1242366

Isomura A, Ogushi F, Kori H, Kageyama R. 2017. Optogenetic perturbation and bioluminescence imaging to analyze cell-to-cell transfer of oscillatory information. Genes Dev 31: 524-535. doi:10.1101/gad.294546.116

Jessberger S, Toni N, Clemenson GD Jr, Ray J, Gage FH. 2008. Directed differentiation of hippocampal stem/progenitor cells in the adult brain. Nat Neurosci 11: 888-893. doi:10.1038/nn .2148

Kim EJ, Ables JL, Dickel LK, Eisch AJ, Johnson JE. 2011. Ascl1 (Mash1) defines cells with long-term neurogenic potential in subgranular and subventricular zones in adult mouse brain. PLOS ONE 6: e18472. doi:10.1371/journal.pone.0018472

Kobayashi T, Mizuno H, Imayoshi I, Furusawa C, Shirahige K, Kageyama R. 2009. The cyclic gene Hes1 contributes to diverse differentiation responses of embryonic stem cells. Genes Dev 23: 1870-1875. doi:10.1101/gad.1823109

Kokubo H, Miyanaga-Tomita S, Nakazawa M, Saga Y, Johnson RL. 2005. Mouse hesr 1 and hesr2 genes are redundantly required to mediate Notch signaling in the developing cardiovascular system. Dev Biol 278: 301-309. doi:10.1016/j.ydbio .2004 .10 .025

Kriegstein A, Alvarez-Buylla A. 2009. The glial nature of embryonic and adult neural stem cells. Annu Rev Neurosci 32: 149184. doi:10.1146/annurev.neuro.051508.135600
Lagace DC, Whitman MC, Noonan MA, Ables JL, DeCarolis NA, Arguello AA, Donovan MH, Fischer SJ, Farnbauch LA, Beech $\mathrm{RD}$, et al. 2007. Dynamic contribution of nestin-expressing stem cells to adult neurogenesis. I Neurosci 27: 1262312629. doi:10.1523/JNEUROSCI.3812-07.2007

Lo L-C, Johnson JE, Wuenschell CW, Saito T, Anderson DJ. 1991. Mammalian achaete-scute homolog 1 is transiently expressed by spatially restricted subsets of early neuroepithelial and neural crest cells. Genes Dev 5: 1524-1537. doi:10.1101/gad .5.9.1524

Lugert S, Basak O, Knuckles P, Haussler U, Fabel K, Götz M, Haas CA, Kempermann G, Taylor V, Giachino C. 2010. Quiescent and active hippocampal neural stem cells with distinct morphologies respond selectively to physiological and pathological stimuli and aging. Cell Stem Cell 6: 445-456. doi:10 .1016/j.stem.2010.03.017

Madisen L, Zwingman TA, Sunkin SM, Oh SW, Zariwala HA, Gu H, Ng LL, Palmiter RD, Hawrylycz MJ, Jones AR, et al. 2010. A robust and high-throughput Cre reporting and characterization system for the whole mouse brain. Nat Neurosci 13: 133-140. doi:10.1038/nn.2467

Martynoga B, Mateo JL, Zhou B, Andersen J, Achimastou A, Urbán N, van den Berg D, Georgopoulou D, Hadjur S, Wittbrodt J, et al. 2013. Epigenomic enhancer annotation reveals a key role for NFIX in neural stem cell quiescence. Genes Dev 27: 1769-1786. doi:10.1101/gad.216804.113

Mason HA, Rakowiecki SM, Raftopoulou M, Nery S, Huang Y, Gridley T, Fishell G. 2005. Notch signaling coordinates the patterning of striatal compartments. Development 132: 4247-4258. doi:10.1242/dev.02008

Mira H, Andreu Z, Suh H, Lie DC, Jessberger S, Consiglio A, Emeterio JS, Hortigüela R, Marqués-Torrejón MÁ, Nakashima $\mathrm{K}$, et al. 2010. Signaling through BMPR-IA regulates quiescence and long-term activity of neural stem cells in the adult hippocampus. Cell Stem Cell 7: 78-89. doi:10.1016/j .stem.2010.04.016

Miyazono K, Miyazawa K. 2002. Id: a target of BMP signaling. Sci STKE 151: pe40. doi:10.1126/stke.2002.151.pe40

Mizutani K, Yoon K, Dang L, Tokunaga A, Gaiano N. 2007. Differential Notch signalling distinguishes neural stem cells from intermediate progenitors. Nature 449: 351-355. doi:10 $.1038 /$ nature06090

Morshead CM, Reynolds BA, Craig CG, McBurney MW, Staines WA, Morassutti D, Weiss S, van der Kooy D. 1994. Neural stem cells in the adult mammalian forebrain: a relatively quiescent subpopulation of subependymal cells. Neuron 13: 1071-1082. doi:10.1016/0896-6273(94)90046-9

Mourikis P, Sambasivan R, Castel D, Rocheteau P, Bizzarro V, Tajbakhsh S. 2012. A critical requirement for Notch signaling in maintenance of the quiescent skeletal muscle stem cell state. Stem Cells 30: 243-252. doi:10.1002/stem.775

Nam H, Benezra R. 2009. High levels of Id1 expression define B1 type adult neural stem cells. Cell Stem Cell 5: 515-526. doi:10 $.1016 /$ j.stem.2009.08.017

Noda N, Honma S, Ohmiya Y. 2011. Hes1 is required for contact inhibition of cell proliferation in 3T3-L1 preadipocytes. Genes Cells 16: 704-713. doi:10.1111/j.1365-2443.2011.01518.x

Nyfeler Y, Kirch RD, Mantei N, Leone DP, Radtke F, Suter U, Taylor V. 2005. Jagged1 signals in the postnatal subventricular zone are required for neural stem cell self-renewal. EMBO J 24: 3504-3515. doi:10.1038/sj.emboj.7600816

Parras CM, Galli R, Britz O, Soares S, Galichet C, Battiste J, Johnson JE, Nakafuku M, Vescovi A, Guillemot F. 2004. Mash1 specifies neurons and oligodendrocytes in the postnatal brain. EMBO J 23: 4495-4505. doi:10.1038/sj.emboj.7600447 
Pastrana E, Cheng L-C, Doetsch F. 2009. Simultaneous prospective purification of adult subventricular zone neural stem cells and their progeny. Proc Natl Acad Sci 106: 6387-6392. doi:10.1073/pnas.0810407106

Pilz G-A, Bottes S, Betizeau M, Jörg DJ, Carta S, Simons BD, Helmchen F, Jessberger S. 2018. Live imaging of neurogenesis in the adult mouse hippocampus. Science 359: 658-662. doi:10.1126/science.aao5056

Sang L, Coller HA, Roberts JM. 2008. Control of the reversibility of cellular quiescence by the transcriptional repressor HES1. Science 321: 1095-1100. doi:10.1126/science.1155998

Seri B, García-Verdugo JM, McEwen BS, Alvarez-Buylla A. 2001. Astrocytes give rise to new neurons in the adult mammalian hippocampus. J Neurosci 21: 7153-7160. doi:10.1523/JNEUR OSCI.21-18-07153.2001

Shi X, Garry DJ. 2006. Muscle stem cells in development, regeneration, and disease. Genes Dev 20: 1692-1708. doi:10.1101/ gad.1419406

Shimojo H, Ohtsuka T, Kageyama R. 2008. Oscillations in Notch signaling regulate maintenance of neural progenitors. Neuron 58: 52-64. doi:10.1016/j.neuron.2008.02.014

Shimojo $\mathrm{H}$, Isomura A, Ohtsuka T, Kori H, Miyachi $\mathrm{H}$, Kageyama R. 2016. Oscillatory control of Delta-like1 in cell interactions regulates dynamic gene expression and tissue morphogenesis. Genes Dev 30: 102-116. doi:10.1101/gad.270785.115

Srinivas S, Watanabe T, Lin CS, William CM, Tanabe Y, Jessell TM, Costantini F. 2001. Cre reporter strains produced by tar- geted insertion of EYFP and ECFP into the ROSA26 locus. BMC Dev Biol 1: 4. doi:10.1186/1471-213X-1-4

Urbán N, van den Berg DLC, Forget A, Andersen J, Demmers JAA, Hunt C, Ayrault O, Guillemot F. 2016. Return to quiescence of mouse neural stem cells by degradation of a proactivation protein. Science 353: 292-295. doi:10.1126/science.aaf4802

Veeraraghavalu K, Choi SH, Zhang X, Sisoda SS. 2010. Presenilin 1 mutants impair the self-renewal and differentiation of adult murine subventricular zone-neuronal progenitors via cell-autonomous mechanisms involving Notch signaling. J Neurosci 30: 6903-6915. doi:10.1523/JNEUROSCI.0527-10.2010

Viñals F, Reiriz J, Ambrosio S, Bartrons R, Rosa JL, Ventura F. 2004. BMP-2 decreases Mash1 stability by increasing Id1 expression. $E M B O J$ 23: 3527-3537. doi:10.1038/sj.emboj .7600360

Wang X, Chen X, Yang Y. 2012. Spatiotemporal control of gene expression by a light-switchable transgene system. Nat Methods 9: 266-269. doi:10.1038/nmeth.1892

William DA, Saitta B, Gibson JD, Traas J, Markov V, Gonzalez DM, Sewell W, Anderson DM, Pratt SC, Rappaport EF, et al. 2007. Identification of oscillatory genes in somitogenesis from functional genomic analysis of a human mesenchymal stem cell model. Dev Biol 305: 172-186. doi:10.1016/j.ydbio 2007.02.007

Yu X, Alder JK, Chun JH, Friedman AD, Heimfeld S, Cheng L, Civin CI. 2006. HES1 inhibits cycling of hematopoietic progenitor cells via DNA binding. Stem Cells 24: 876-888. doi:10.1634/stemcells.2005-0598 


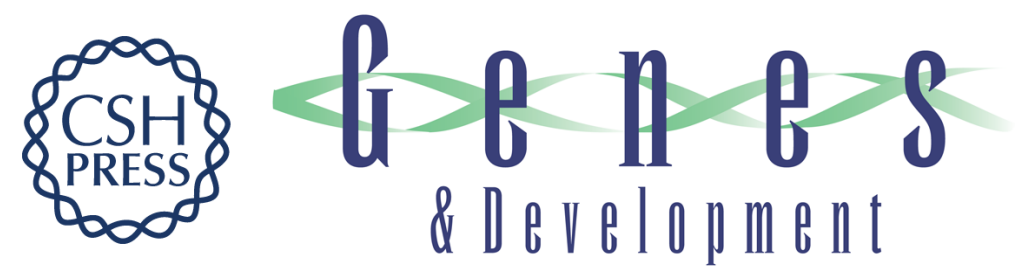

\section{High Hes1 expression and resultant Ascl1 suppression regulate quiescent vs. active neural stem cells in the adult mouse brain}

Risa Sueda, Itaru Imayoshi, Yukiko Harima, et al.

Genes Dev. 2019, 33: originally published online March 12, 2019

Access the most recent version at doi:10.1101/gad.323196.118

\section{Supplemental http://genesdev.cshlp.org/content/suppl/2019/03/12/gad.323196.118.DC1 \\ Material}

Related Content

HES1, two programs: promoting the quiescence and proliferation of adult neural stem cells

Lachlan Harris and François Guillemot

Genes Dev. May , 2019 33: 479-481

References This article cites 60 articles, 27 of which can be accessed free at:

http://genesdev.cshlp.org/content/33/9-10/511.full.html\#ref-list-1

Articles cited in:

http://genesdev.cshlp.org/content/33/9-10/511.full.html\#related-urls

Creative This article, published in Genes \& Development, is available under a Creative Commons

Commons

License (Attribution-NonCommercial 4.0 International), as described at

License http://creativecommons.org/licenses/by-nc/4.0/.

Email Alerting Receive free email alerts when new articles cite this article - sign up in the box at the top Service right corner of the article or click here.

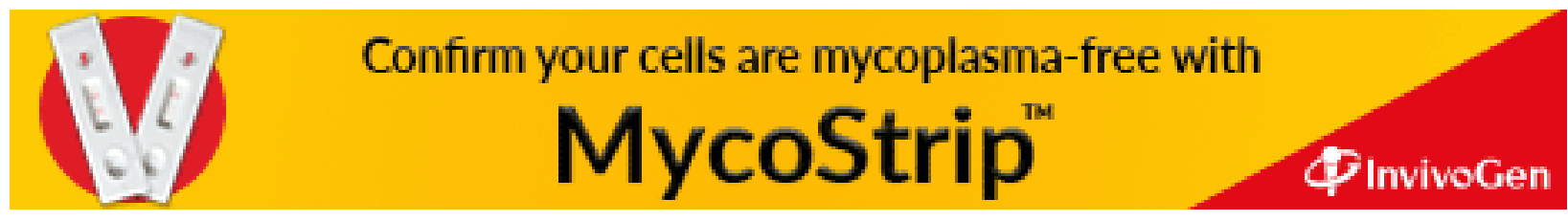

